\title{
Die Hocharistokratie. Grundbesitz, Karrieren, Lebensräume
}

\begin{abstract}
Der Beitrag skizziert die soziale Position des niederösterreichischen Hochadels vor dem Hintergrund des gesellschaftlichen Wandels im langen i 9. Jahrhundert. Im Mittelpunkt stehen die innere Gliederung des Adels, die Dimensionen seines Grundbesitzes, Wirtschaftsführung und Vermögen, Berufskarrieren bei Hof, in Diplomatie, Verwaltung, Militär und Kirche sowie adelige Lebensräume in der Residenz Wien und auf den Landgütern. Die Auseinandersetzung mit verschiedensten Facetten eines distinktiv adeligen Lebensstils verweist nicht nur auf Kontinuitäten wie Brüche in überkommenen Verhaltens- und Wertmustern, sondern zeigt auch die Chancen und das Scheitern autonomer Lebensentwürfe von Frauen und Männern. Die breit angelegte Darstellung von adeligen Mentalitäten, Lebensformen und Handlungsoptionen enthüllt die ambivalenten Folgen des fortschreitenden Elitenwandels. Trotz des Verlustes alter Machtpositionen eröffneten die Nutzung wirtschaftlicher Chancen, die Bildung von Netzwerken über Standesgrenzen hinweg sowie ein ungebrochener Paternalismus die Möglichkeiten für eine Selbstbehauptung der alten Hocharistokratie.
\end{abstract}

The High Nobility. Landed Property, Careers, Living Spaces. This chapter outlines the social position of Lower Austria's high nobility against the background of social change in the long $19^{\text {th }}$ century. It focuses on the inner structure of the nobility, the dimensions of their landed property, economic management and wealth, professional careers at the court, in diplomacy, administration, the military and the church, and noble living spaces in the Vienna Residence and on the estates. The examination of various facets of a distinctly aristocratic lifestyle points to continuities as well as breaks in traditional patterns of behaviour and values; it also shows the chances and failures of autonomous life plans of women and men. This broad depiction of noble mentalities, ways of life and options for action reveals the ambivalent consequences of the progressive change in elites. Despite the loss of old positions of power, the exploitation of economic opportunities, the formation of networks across boundaries of social class and an unbroken paternalism opened up opportunities for the old high aristocracy to assert itself.

Keywords: social elites, elite transformation, aristocratic lifestyle, paternalism, Habsburg Monarchy 